\title{
Economic security as the basis for sustainable development of the territories of different levels
}

\author{
Elena Efimova ${ }^{1, *}$, Tatyana Lukashenok ${ }^{1}$, and Dina Prostova ${ }^{2}$ \\ ${ }^{1}$ Regional, Municipal Economics and Governance Department, Ural State University of Economics, \\ Ekaterinburg, 620144, Russia \\ ${ }^{2}$ Department of Foreign Languages, Ural State University of Economics, Ekaterinburg, 620144, \\ Russia
}

\begin{abstract}
Sustainable development of territories at the national and global level has become a topical area of research since the end of the XX century. At the same time for each national economy individual priorities of achieving sustainability are defined. The paper is analysed the theoretical basis of the concept of "sustainable development" of the territory. The study reveals the direct link between sustainable development and economic security at each territorial level: from macro to micro. The analysis of domestic and foreign scientific studies, normative documents allows determining that ensuring economic security at different territorial levels contributes to the achievement of sustainability in their socio-economic development, and many indicators are identical for both security and sustainability assessment. The authors present a model of sustainable territories' development of different levels on the basis of the implementation of the directions in the sphere of economic security.
\end{abstract}

\section{Introduction}

Sustainable development at the present time is determined by the efficiency and rationality of ways of economic management and economic growth which is based on them. And for each national economy there are "individual" limits and rates of growth, which are determined by differences in the achieved level of economic development, availability (quantity) of resources and possibilities of their use. In scientific researches there are different types and models of economic growth: intensive, extensive, zero, "green", sustainable growth, and within ecology there is a concept of "steady state economy". Sustainability of national economy is also determined by the state of its security, i.e. the state's protection from the influence of negative external and internal factors. This sphere represents a certain system, which requires monitoring and evaluation. The issues of sustainable development and economic security justify the research in the field of search of ways to improve living standards and well-being of people.

\footnotetext{
* Corresponding author: levstrelkov@mail.ru
} 


\section{Sustainability Studies}

The concept of sustainable development became a relevant agenda for the entire world community at the end of the 20th century, when the report of the World Commission on Environment and Development "Our Common Future" was published in 1987 [1]. Human well-being has become a common goal of the world community and depends on the contribution of each country to achieve it. In 1992, the United Nations Environment and Development held a conference, the outcome of which was the adoption of the Concept of Sustainable Development [2]. The concept contains specific recommendations to Governments to develop national strategies in the sphere of economic development and environmental protection. The development of these strategies has a legal and political nature, has an impact on foreign policy relations between countries, as it affects national interests in the field of economy, environmental protection, opportunities for socioeconomic development. The UN concept makes specific demands to the modern generation in the sphere of rational use of the Earth's resources.

In Russia's legislative documents, the term "sustainable development" is applied to two areas: ensuring a decent standard of living and preserving the traditions of indigenous peoples living in the Russian Federation. In Russia's legislative documents, the term "sustainable development" is applied to two areas: ensuring a decent standard of living and preserving the traditions of indigenous peoples living in the Russian Federation [3-4]. The considered documents have a social orientation of public development. Economic activity and economic growth in national economies in the last century were extensive in nature, where the main goal was economic gain and thus the economic principle prevailed over the social. But since the second half of the twentieth century, many countries have seen a shift toward social justice, which has been given an important "instrumental role in shaping well-being [5], Such a system of economic management modern scientists name "socioeconomic"[5], which has the signs of sustainability that is based on the achievement of human well-being and society.

Stability of economic system is determined by its most important property - its integrity, and the change of any element of the system, affects others, which leads to a change in the whole system. The gap at the level of managerial (strategic) decisions, when "economic policy is developed and exists in isolation from the social" or vice versa, "the role of economic factors and consequences in social policy is poorly calculated", ultimately leads to very negative consequences [6]. Scholars find socioeconomics to be directly involved in politics and to be "conscious of the normative processes of its work"[7].

After the 1992 UN conference, many countries adopted recommended legislative documents. In Russia, the Concept of Sustainable Economic Growth and Development was adopted, prior to which the National Environmental Action Plan was implemented. In 1994, a Presidential Decree approved the State Strategy of the Russian Federation on Environmental Protection and Sustainable Development [8] and two years later a Presidential Decree approved the Concept of Russia's Transition to Sustainable Development [9], which presents a system of perspective provisions of the country on the threshold of the XXI century.

The topic of sustainable development is of research interest to Russian and foreign scientists. In this area we can cite studies by Belousov, Kuznetsova, Krasnoschekov, Rosenberg, Sinitsina, Pasenov, Pashkevich, Shapoval and others.

Among the foreign scientists who contributed to the study of the problems of this sphere, we can quote such as J. Galbraith, A. Aron, R. Carson, D.H. Meadows, J.L. Meadows, J. Randers and others. In modern studies scientists highlight the inextricable connection of the concept of sustainable development with the well-being of people. G.H. Brundtland connects sustainable development with the ability of human society to meet its 
needs without compromising the ability of future generations to meet their needs [10]. Dempsey, Bramley, Power, Brown point out that "sustainable development is a widely used term, which in recent years has had an increasing influence on planning, housing and urban policy in Britain. In understanding the essence of sustainable development the authors link environmental problems with economic and social aspects [11]. Liverman et al. defined "... sustainability is the indefinite survival of the human species (with a quality of life beyond mere biological survival) through the maintenance of basic life-support systems (air, water, land) and the existence of the infrastructure and institutions that distribute and protect the components of those systems [12]. In the cited studies the basic essence of the UN Concept of 1992 is evident.

The creation of sustainable development of the country is closely connected with the state of its economic security. Economic security is the interest of the state level, where the basis for sustainable development of all lower territorial levels is formed in general, which has an important integrative meaning for the definition of state strategic priorities, determined by national interests.

\section{About the importance of economic security in sustainable development}

The emergence and development of national state interest predetermines the formation of the concept of "economic security". Questions of security of the country are a subject of the interest of Russian and foreign scientists. J.-J. Rousseau writes about the importance of safety that "the concern for self-preservation and security is the most important of all the concerns of the state" [13]. Other researchers define safety as "the absence of danger, safety, reliability [14], or as "a state in which there is no danger; there is protection from danger" [15].

The concept of economic security is legislatively enshrined in the 1992 law of the Russian Federation "On Security" [16], where its essence is defined in the state of protection of the vital interests of an individual, society and the state from internal and external threats, which, in fact, indicates the recognition of this problem. This law gives the concept of security, identifies its objects and subjects, threats and directions of ensuring [17].

A great contribution to the formation of the state economic security system was made by the now defunct Presidential Decree "On the State Strategy of Economic Security of the Russian Federation", which contains a description of problems in this area, which presents the following interpretation of security as "the state of protection of economic interests of individuals, society and the state from internal and external threats, on the basis of the independence, efficiency and competitiveness of the economy [18].

In modern Russia, the special importance of economic security issues is highlighted in legislative documents: National Security Strategy of the Russian Federation until 2020 [19], in the Strategy of economic security of the Russian Federation up to 2030 [20], where a lot of attention is paid to security issues, including 19 evaluation criteria at the national level, formed after the economic crisis of 2008.

The development of modern social relations is characterized by an increasing rate of change in the established socio-economic relations and political environment. In general, this trend is a global trend, but it operates at the state, regional and municipal levels. The process of globalization of the world economic system reinforces this trend, which causes the need to address the issue of resource provision of the needs of the population both at the scale of the world community and at the level of public legal entities (state, region, municipality). In accordance with that the economic security issues should be studied at different levels: from the individual to the state. 
The state of national security as a whole depends on the formation of the state of security at each of the territorial levels, which requires a comprehensive approach in the study. Analysis of data on three planes (analysis of the existing situation, assessment of events preceding the current state, and forecasting of potential changes) is based on a comprehensive approach and allows for a more complete, versatile assessment. In this paper we have summarized and systematized some aspects of economic security for each level. Let us briefly characterize each of the levels to show the links between the state of the economic security and the sustainable territories' development.

The economic security of the state is the basis of the welfare of the population and sustainable economic development of the country, including individual industries, regions, municipalities, including at the level of enterprises and organizations, regardless of ownership. In other words, we define the economic security of the state as the starting point in the system of assessing the stability of the socio-economic situation of different territorial levels.

The relevance of this direction of research is confirmed by the existence of many scientists' opinions on methods for assessing the economic security of the state. In this area a group of scientists from the Institute of Economics of the Russian Academy of Sciences proposed a set of indicators grouped into three types: macroeconomic (GDP volume), private socio-economic, revealing general trends of macroeconomic indicators (share of investment in fixed capital, unemployment rate, etc.), functional and sectoral level indicators (for defense spending, share of food imported, etc.) [21].

The procedure for assessing the level of economic security is regulated by normative legal acts, where, the Strategy of economic security of the Russian Federation, approved by Presidential Decree in 2017 [22] is one of the main types of documents in this sphere. This Strategy proposes 40 indicators to monitor the security situation; every one indicator has been analyzed by the relevant federal ministries with statistical data, which are publicly available on the website of the Federal State Statistics Service.

In addition to the Economic Security Strategy, in the regulatory and legal approach to assessing economic security at the state level is the order of the Ministry of Economic Development of the Russian Federation 2018 N 532, which approves the procedure for organizing work to monitor and assess the state of economic security of the Russian Federation [23]. The document establishes the need to prepare an annual report on the state of Russia's economic security and submit it to the President of the Russian Federation. The document contains the methodology of indicative assessment of the state of the Russian Federation's economic security, which is currently, in our opinion, is a universal, comprehensive, because it allows taking into account the features of the contribution of each of the 40 indicators of economic security in achieving overall stability and the ability to prevent threats to the state economy. It should be noted that to date, the application of this methodology is complicated by the lack of legally established threshold values for each indicator.

The lack of a unified approach to the formation of thresholds and their consolidation at the legal level generates the inevitability of finding other ways to determine the critical level, such as methods of expert assessments, analogy, mathematical modeling and other methods.

The economic security of the region reveals the individual characteristics and trends of the state of economic security of the state, with its own characteristics due to the high degree of differentiation of development of the regions in the Russian Federation, including the presence of a contradictory fact: the incorporation of regions into the system of state power, on the one hand, the existence of regional independence, on the other. Here a special relevance acquires such an indicator for assessing the security of the state as the level of economic integration of the subjects of the Russian Federation. 
In understanding the economic security of the region it is not important to consider only the need to minimize external and internal threats, but the ability of the regional economy to neutralize them through mechanisms of self-regulation and self-organization, while it is not advisable to consider only direct threats, but also "missed opportunities in making ineffective decisions" [24].

To achieve the goals of sustainable development and economic security, an important aspect is to reduce the degree of differentiation between regions. In this sphere one of the important directions of the state policy is to balance the development of the regions and to ensure their economic security, which is conditioned by the efficiency of territorial planning, the development of agglomerations and the creation of clusters. When determining the system for assessing the economic security of a region it is necessary to take into account its characteristics (natural-resource, socio-economic, etc.).

There is no single approved methodology for determining the level of economic security of the region in the normative-legal sphere, but it should be noted the increasing interest of researchers to this topic in recent years and the presence of different points of view reflecting the situation in the real economy, in the economic, social and innovative development of regions.

The assessment of economic security at the regional level is directly linked to the sustainability the territories' development of this level, as it includes a variety of indicators of the effectiveness of the production activities of the leading sectors of the region, indicators characterizing the conditions and quality of life, employment and demographic processes, indicators that determine the level of financial stability of the region, the evaluation of scientific potential, the degree of development and implementation of innovative technologies.

Assessment of economic security at the municipal level has issues of regulatory and legal nature, but this circumstance does not reduce its importance in achieving an optimal state in the field of security and sustainable development.

In the normative-legal sphere the basis of the research of the issues of economic security of municipal formations is the law on strategic planning № 172-FZ [25], which has a mandatory character, aimed at ensuring the economic security of not only municipalities, but also regional and federal levels.

The problem is the lack of independence of municipal government in the management of municipal development, including the management of the state of economic security. Scientific research and normative documents reveal that to date some issues and problems of economic security and sustainability of development of municipalities remain unresolved $[18,25]$. It should be noted that the economic security of the municipality is based on the important directions of the Economic Security Strategy of the Russian Federation.

The welfare of the population, the indicators which are a part of the system of indicators of national economic security, starts to be formed at the municipal level. The interests of the population of the municipality consist of ensuring and maintaining a decent standard of living, effective and rational use of the economic potential of the territory, the implementation of an independent socio-economic policy of the municipality, which are the basis of economic security in general, and the concept of security is obvious and understandable to everyone. It should be noted that the assessment of the economic security of the municipality allows evaluation at all higher levels, and, in addition, the security at the municipal level is interconnected "with the general scheme of analysis and indicators used at the federal, regional, sectoral levels" [25].

Researchers include in the term economic security of a municipality the ability to use the resource potential of the territory and define it as "the state of sustainability of the economic sector of the municipality, ensuring its socio-economic development within the 
national economy under the impact of internal and external economic threats, achieved through the implementation of its internal resource potential and adequate management" [26]. Assessment of economic security at the municipal level is a relatively new area of research, attracting the scientific interest of various authors.

The balance in the development of municipalities and the prevention of sharp fluctuations in certain areas of their activities are determined by Law No. 131-FZ [27]. T.L. Silina thinks that "the need for municipal economic security is a basic, fundamental need, as the life of an individual, family, and various associations of people, including society and the state" [28], therefore, the achievement of sustainability of municipal development should be defined as basic in the system of sustainable development of the entire national economy.

Under the conditions of increased uncertainty in the external environment (geopolitical situation, changes in the forms and methods of state regulation of enterprises, increased competition, etc.), the emergence of internal threats, including the transition to a new technological and world economic order, affect the economic security and sustainability of all territorial levels, affecting all economic entities. In other words, the process of globalization "penetrates" all territorial levels and "tests the strength" of the conditions of security and sustainability of territories, as well as promising directions for their formation and strengthening.

In foreign studies, scientists highlight the components of security: international and national, where the attributes of international security are global and regional security, at the national level there are state, public and private security. In turn, global security is a system of international and environmental security relations against threats that can destabilize the world, cause a global crisis; and regional security is a set of economic, environmental, legal, geopolitical and other conditions, which should ensure the security of state interests, regional development, financial stability, infrastructure and business development, as well as affect the development of internal and external security. The component of private security in the context of national security, according to Glaser, is divided into enterprise security and personal security [29].

Tang proposes a rethinking of economic security as a result of world globalization. He believes that economic security is not only about adequate financial security for survival, but also about fighting poverty and unemployment, acting against dangers and threats, and preventing lawbreaking and corruption. Security is an existential issue and a priority for the development of general state security [30]. Among the relevant is scientific research in the field of personal security.

Summarizing the above, we identify a direct link between sustainable development and economic security. As a result of the transformation of economic activity of society, there are issues and problems that are in the sphere of intersection of the concepts of security and sustainability, which require study in the context of national interests and strategic priorities.

The authors of the research propose a model that ensures the formation of conditions for sustainable territories' development of different levels (state, regional, municipal) as a result of the implementation of directions to achieve, maintain and strengthen the proper level of economic security of the particular object (territory). 


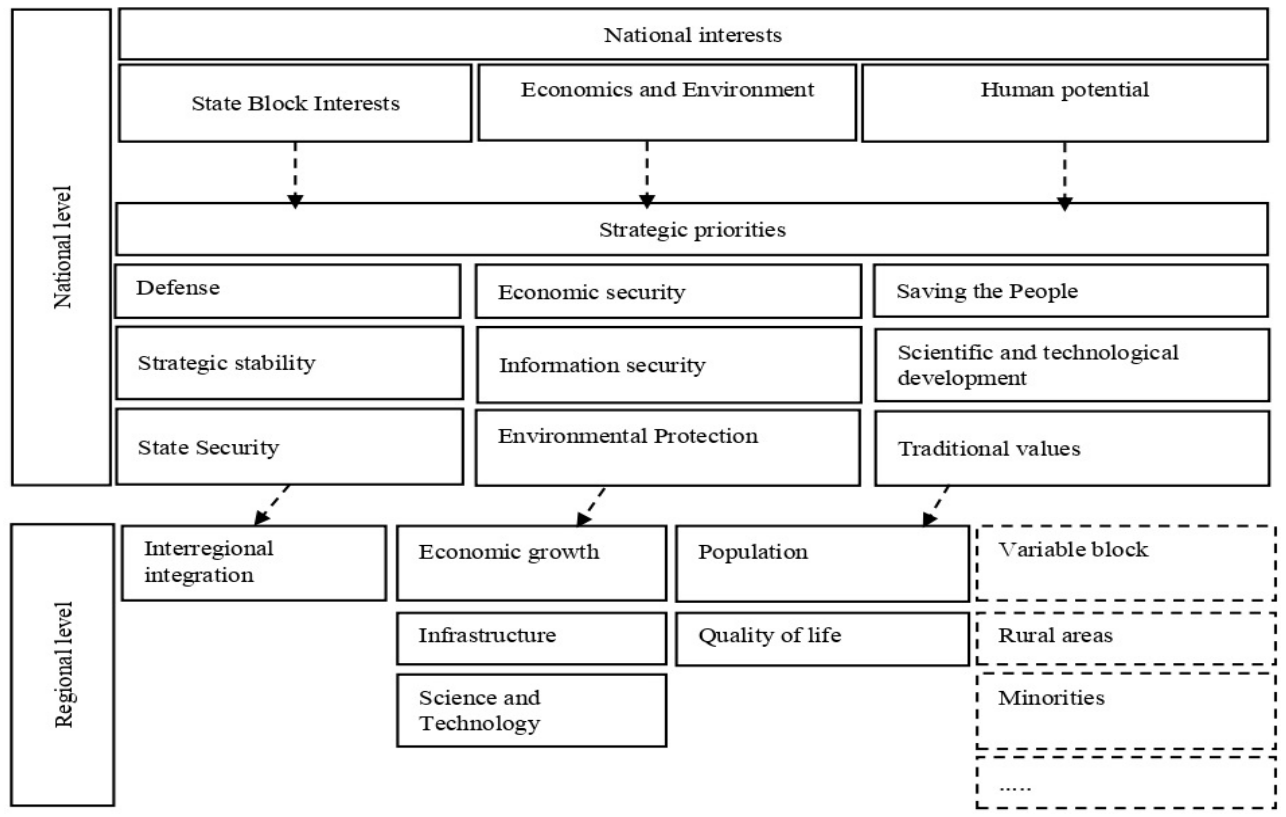

\begin{tabular}{|c|c|c|c|}
\hline \multirow{3}{*}{ 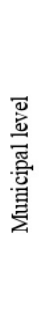 } & \multicolumn{3}{|c|}{ Local interests } \\
\hline & Economic self-reliance & Human potential & Territory development \\
\hline & Municipal Property Management & Saving the People & Infrastructure \\
\hline
\end{tabular}

Fig. 1. The model of sustainable territories' development of different levels.

This model is built on the basis of regulatory and legislative documents of the Russian Federation [31-35], where national interests and strategic priorities of Russia are a guide to sustainable development in the long-term perspective and form the top (national) level of economic security. National interests and strategic national priorities are grouped by the authors in such a way as to ensure the achievement of the state's sustainable development goals. The regional level of the model is decomposed from the national level, but the main blocks undergo some transformation, taking into account the specifics of regional development. Thus, "state block interests" at the regional level are achieved through "interregional integration"; the block "economy and ecology" is transformed into indicators of regional "economic growth", which is ensured through the development of "infrastructure" and "science and technology"; "human potential" at the regional level is revealed through control of "population size" and ensuring "quality of life". At the regional level there is also a variable block, the content which will vary depending on the specialization of the region, the level of economic development, the peculiarities of territorial location, the presence of traditional cultures and other factors. The importance of taking into account the above factors is confirmed by the fact that the term "sustainable development" is enshrined in legislation in relation to two areas: ensuring a decent standard of living and preservation of the traditions of small indigenous peoples living in the 
Russian Federation [34-35], as well as development of infrastructure and quality of life in rural territories $[4 ; 35]$.

An important level of formation of national sustainable development is the level of local government. The amendments to the Constitution of the Russian Federation adopted in 2020 united the bodies of state power and the bodies of local self-government into a single system of public authority, which contributes to the need to consider the municipal level as an element of national sustainable development. In order to ensure sustainable development at the municipal level the authors propose three main blocks: "economic selfsufficiency" (important in conditions of heterogeneous development of municipalities within one region), "human potential" (as the basis for the formation of a territory) and "territorial development" (it becomes relevant for achieving economic self-sufficiency). Each of the proposed blocks includes basic directions, and can also be complemented by variant directions, which are determined taking into account the existing problems in the territory of the municipality.

The model proposed by the authors will make it possible to achieve the goals of sustainable territories' development of different levels through the implementation of directions to ensure the economic security of the territory. Thus, the synergistic effect will be achieved and the simultaneous solution of two fundamental tasks will be carried out: ensuring the economic security of the territory and the functioning of the territory according to the scenario of sustainable development.

\section{References}

1. Report of the World Commission on Environment and Development, Our Common Future (1987). Access mode: http://www.un.org/ru/ga/documents/gakey.shtml

2. E. Sinitsina, The concept of sustainable development. Access mode: http://cloudwatcher.ru/analytics/2Mew/72/

3. On the Concept of Sustainable Development of the Small Indigenous Peoples of the North, Siberia and the Far East of the Russian Federation Order of the Government of the Russian Federation № 132-r of 04.02.2009 (2009)

4. On approval of the action plan for the implementation in 2016-2025 of the concept of sustainable development of small indigenous peoples of the North, Siberia and the Far East of the Russian Federation, Order of the Government of the RF of 25.08.2016 № 1792-p (2016)

5. F. M. Borodkin, Social Sciences and Modernity, 5 (2006)

6. M. A. Shabanova, SPERO, 7 (2007)

7. A. Etzioni, Economic Sociology, 3, 1 (2002)

8. On the State Strategy of the Russian Federation on Environmental Protection and Sustainable Devel. Presidential Decree № 236 dated February 4, 1994 (1994)

9. On the Concept of Russia's Transition to Sustainable Development Presidential Decree № 440 dated April 1, 1996 (1996)

10. G. H. Brundtland, Report of the World Commission on Environment and Development: Our Common Future (1987). Access mode: http://www.undocuments.net/our-common-future.pdf

11. N. Dempsey, G. Bramley, S. Power, C. Brown, Sustainable Development (2011)

12. D. M. Liverman, M. E. Hanson, B. J. Brown, Environmental Management, 12, (1988)

13. J.-J. Rousseau, On the social contract or Principles of political law. Access mode: http://www.civisbook.ru/ 
14. V. I. Dahl, The Dictionary of the Living Great Russian Language, 4 (1) (2020)

15. S. I. Ozhegov, Explanatory dictionary of the Russian language (2015)

16. On Security: Law of the Russian Federation, 2446-I (1992)

17. V. N. Moshkin, Modern scientific research and innovations, 7 (2016)

18. On the state strategy of economic security of the Russian Federation Presidential Decree № 608 of 29 Apr. 1996 (1996)

19. On the National Security Strategy of the Russian Federation until 2020 Presidential Decree № 537 of 12.05.2009 (2009)

20. Strategy of economic security of the Russian Federation for the period up to 2030: approved by the Decr. of the President of the RF № 208 from May 13, 2017 (2017)

21. E. B. Dvoryadkina, Y.P. Silin, N.V. Novikova, Economic security (2016)

22. Strategy of economic security of the Russian Federation for the period until 2030: approved by Presidential Decr. № 208 of May 13, 2017 (2017)

23. On organizing work to monitor and assess the state of economic security of the Russian Federation in the Ministry of Economic Development of the Russian Federation, Order of the Ministry of Economic Development of the RF № 532 of October 3, 2018 (2018)

24. G. M. Fedorov, K. Y. Voloshenko, V. V. Gorochnaya, et al, Problems of Economic Security in the Regions of the Western Frontier of Russia: Monograph (2019)

25. A. N. Asanov, Economics and Entrepreneurship, 9-2, 62 (2015)

26. O. B. Ganin, I. O. Ganin, Ars Administrandi, 1 (2015)

27. On General Principles of Organization of Local Self-Government in the Russian Federation, 131-FZ (2003)

28. T. L. Silina, Fundamental research, 9, 5 (2014)

29. C. Glaser, World Politics, 50, 1 (1997)

30. S. M. Tang, Contemporary Politics, 21, 1 (2015)

31. On the National Security Strategy of the Russian Federation, Presidential Decr. of 02.07.2021 № 400 (2021)

32. On approval of the Strategy of spatial development of the Russian Federation for the period up to 2025, Decr. of the Gov. of the RF of 13.02.2019 № 207-p (2019)

33. On approval of the Strategy of sustainable development of rural territories of the Russian Federation for the period up to 2030, Decr. of the Gov. of the RF from 02.02.2015 № 151-p (2015)

34. On the Concept of Sustainable Development of Indigenous Minorities of the North, Siberia and Far East of the Russian Federation, Decr. of the Gov. of the RF of 04.02.2009 № 132-p (2009)

35. On the action plan for implementation in 2018 - 2020 of the Strategy for sustainable development of rural areas of the Russian Federation for the period up to 2030, Decr. of the Gov. of the RF from 30.01.2018 № 118-p (2018) 